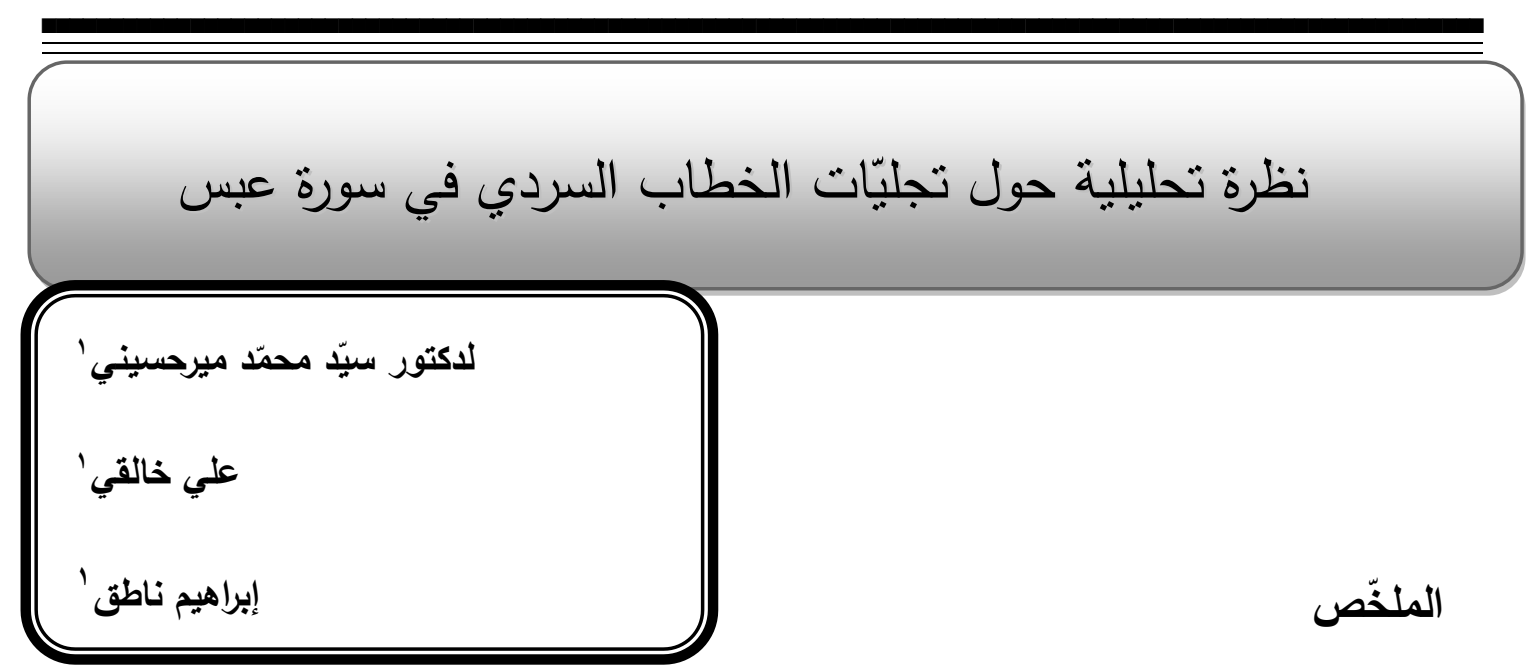

يعود السرد القصصى في القرآن الكريم لله سبحانه و تعالى فهو الذي يقصّ أحسن القصص الصادقة التي تحمل أشرف غاية و أكرم مقصد و أقوم طريق إذ يؤدي السرد وظيفة مهمة و غاية رئيسة في القصّة القرآنية هي الروئية التي تقدم للإنسان العقائد و المبادئ و الأفكار و العبر التي تتطوي عليها القصّة؛؛ و من هذا المنطلق يستوجب تحليل الرواية وتفكيكها بنيوياً وسردياً دراستها عبر مستوبين: مستوى القصّة (Histoire) ومستوى الخطاب (Discourse).و من ثمّ يتضمن مستوى القصة الأحداث، والثخصيات أو القوى الفاعلة، والفضاء بمعطياته الزمانية والمكانية.أما الخطاب السردي داخل الرواية، فينكبّ على دراسة الملفوظات اللغوية، وتحليل المستويات السردية من منظور ، ووصف، وزمن، وصيغة، وبلاغة، ومعمار • بمعنى أنّ المكونات القصصية تتكلف بها السيميوطيقا السردية. في حين، تهنم البنيوية السردية أو علم السرد (Narratologie) بدراسة الخطاب أو الثكل الذي يرد عليه المنت الحكائي. وإذا كان العلماء الأدب باعتباره بنيوياً سردياً، قد حصر الخطاب أو الثكل في ثناثة محاور كبرى وهي: الرؤية السردية، والصيغة، والزمن السردي. هذه الدراسة تبيّن مستوبات الخطاب السردي عبر تحليل سرد محمّد (ص) و عبداله بن أمّ مكتوم في سورة عبس؛ و المنهج الذي اعتمدناه في هذه المقالة هو المنهج الوصفيّ التحليليّ. الكلمات الاليلة: السرد، سورة عبس، محمّد (ص)، عبداله بن أمّ مكثوم، الخطاب 


\section{- - - -}

تراوح مصطلح السرد بين كونه خطاباً غير منجز أو قصاً أدبياً بقوم به سارد ليس هو الكاتب بالضرورة بل وسيط بين الأحداث و متلقيها (علوش،910 ا: . (1)، و ارتبط به مصطلح السردية الذي يعنى به: الطريقة التي نروى بها القصة أو الخرافة فعلياً، و هي فروع الأدبية (إبراهيم،949 1: 9)، التي بحث في أدبية الأدب أو ما المقومات التي تجعل العمل الأدبي أدبياً، فكانت السردية بحث في ما يجعل القصة أو الرواية، أدباً سردياً، من خلال رواية سلسلة من الوقائع و الأحداث بعد إقامة بعض العلائق بينها (سهر ، 999 ( : Y ( )، و رغم كون علم السرد قديماً في نشأته منذ عام 1 (1)، على يد ايخنباوم في مقالة له بعنوان ״كيف صيغ معطف غوغوله إلا أنه لم يظهر هذا المصطلح إلا في سنة 979 (، على يد ״تذوروف《• و استجماعاً لأركان العملية السردية، فالسرد هو وسيلة توصيل القصة إلى

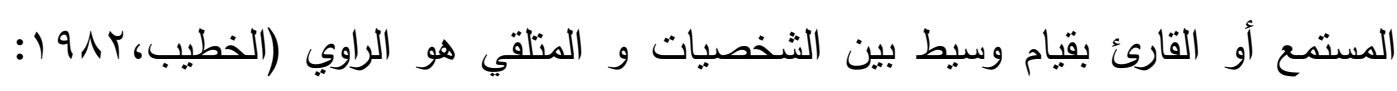
سه ()، و المعتاد، أن تختلف طرائق توصيل الأثر و من خلال هذا الاختلاف، و هو جوهر عمل النقد البنيوي تبيين الطرائق التي أعاد فيها السارد ترتيب الحكاية التي في جوهرها هي أحداث موجودة في محصلتها، لكن تكمن أدبية ساردها في اختيار و إتقان أسلوب إسداء هذه الحكاية التي هي عبارة عن مجموعة من الأحداث، أو من الأفعال السردية تتوق إلى نهاية، أي أنها موجهة نحو غاية، هذه الأفعال السردية تتنظم في إطار سلاسل تكثر أو تقل حسب طول الحكاية أو قصرها كل سلسلة يثد فعالها رباط زمني و منطقي (سهر ،799 (1: (ب)، و يقف إدراك الراوي السارد لتسلسل الأحداث ركناً مههاً في اختبار زاوية النظر التي يطل منها السارد في انتقاء طريقة سرد الأحداث والتي تعد محك التأثثر ، و إحداث الاستجابة المرتجاة، التي لم تتحكم بها نوعية الحدث و تتوعه وأخلاقيته.إنما كيفية أدائه و طرائق توصيله، حتى كان شخصية السارد هنا قبل إقامة الفعل السردي هي شخصية ناقدة للأحداث تعرض رؤيتها 
للأحداث و ليست معنية فقط بنقل الحدث الذي يفترض نقله، فيبرز جراء ذلك، طابع الاختيار و القصدية و رجاء التأثنر؛ مع هذه العناصر الثناثة، تتحقق الأدبية، و تعدد مستويات التلقي، إذ لا قيمة للثيء إذا ما تم نقله من وجود، المرجعي ليكون ذاته منعكساً على صورة منقولة طبق الأصل، فالخلق الأدبي يعني الإضافة والاجتراح أو التغيير واقتراح هوية مخصوصة للشيء مستمدة من خصوصية منتجة وناقلة إلى المنلقي.

\section{- - بلقية البحث: - T}

من الأهمية بمكان الإشارة إلى أنّه لم يوجد حنّى الآن - في ما أعلم - دراسة تتاولت موضوع الخطاب السردي في سورة العبس لقرآن الكريم، الأمر الذي تتجلّى معه جدّة الموضوع. و هناك العديد من الدراسات التي تتاولت موضوع الخطاب السردي في الثعر ، منها فيما يلي:

اتقانات التعبير السردي قراءة في قصص أوان الرحيل لعلي القاسميه، من

الدكتور محمّد صابر عبيد، في مجلة أبحاث كلية التربية الأساسية، المجلد • (، العدد ا. ״المشهد السردي في القرآن الكريم الرؤيا، بؤرة التشكيل السردي《، من الدكتور حبيب مونسي، جامعة بسكرة مجلة قراءات، 1 · r. ״السرد القصصي في ديوان أنشعار الأصمعيه، من الدكتور حاكم حبيب الكريطي،

الالسرد في التشكيل العراقي المعاصر «، من محمّد علي علوان القره غولي،

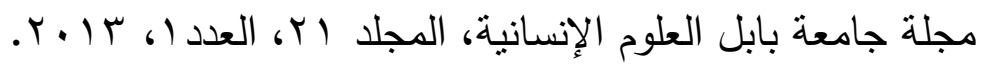
مع هذا لم يبحث عن الخطاب السردي في سورة عبس لقرآن الكريم، و نحنن قمنا بإيراد هذا البحث و تحليل حوله، و اعتمدنا في دراستتا هذه منهجاً وصفيّا، قائماً على التحليل و الإستنتاج في تتاول الطرق الفنّية. 


\section{r-توظيف السرد في سورة عبس:}

عبد الله بن أم مكتوم هو صحابي من صحابة رسول الله وهو ابن خال خديجة أم المؤمنين وأولى زوجات النبى محمد وقد كان عبد الله كان ضريرا. وأم مكتوم هي: عاتكة بنت عبد الله. قيل نزلت الآيات في عبدالله بن أم مكتوم و هو عبداله بن شريح بن مالك بن ربيعة الفهري

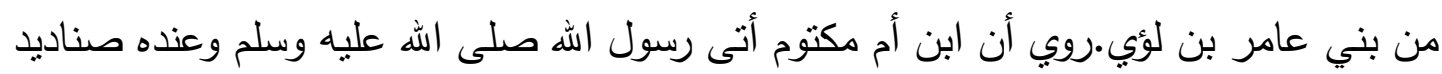
قريش بدعوهم إلى الإسلام فقال با رسول الله علمني مما علمك الله وكرر ذلك ولم بعلم تثاغله بالقوم فكره رسول الله صلى الله عليه وسلم قطعه لكلامه وعبس وأعرض عنه فنزلت فكان رسول الهه صلى اله عليه وسلم يكرمه ويقول إذا رآه مرحبا بمن عاتبني فيه ربي واستخلفه على

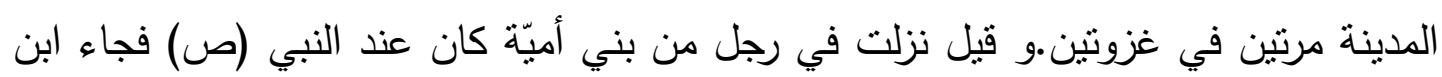
أم مكتوم فلمّا رآه تقذر منه و جمع نفسه و عبس و أعرض بوجها عنه عنه فحكى اله سبحانه

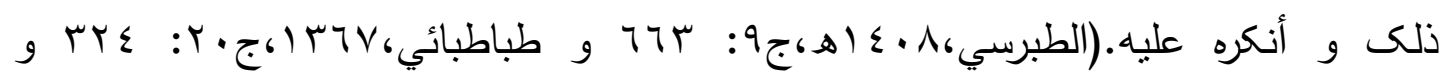

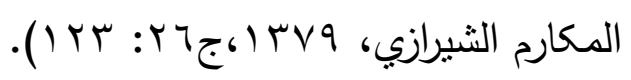




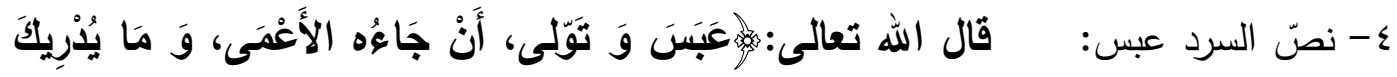

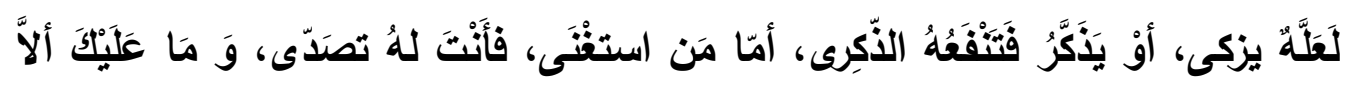

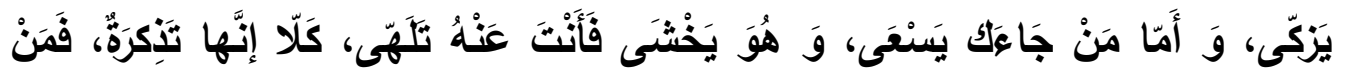

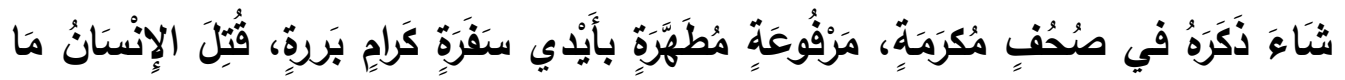

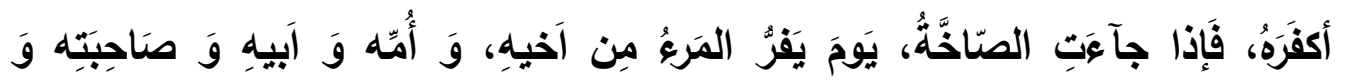

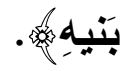

$$
\begin{aligned}
& \text { 0-تحلبل الخطاب السردي لسورة عبس: } \\
& \text { 0-1- المكوّن الإيقاعي: }
\end{aligned}
$$

إنّ مصطلح الإيقاع بظل متميزاً بالتجدّد، تبعّاً لتجدد المعطيات النقدية الراهنة، فعلى صعيد المفهوماتية ألفيناه في لسان العرب: امن إيقاع اللحن والغناء، وهو أن يوقع الألحان و يبينهاه (ابن منظور،ج • (: Y^^). أنّ هذه التعريفات تقوم على مبدأ التجانس في العرض التعبيري، و المحافظة على الإيقاعية بوصفها تقربعاً أدبياً.و في مجال الإيقاع، وجدنا الجاحظ مثنلاً يتحدث عنه، بوصفه ظاهرة تتاغمية تلامس المنن الثعري بقوله: حظ جودة القافية وإن كانت كلمة واحدة أرفع من حظ سائر البيت (الجاحظ،1979 19 V9). و لعل هذه الإشارة التي تجعل القافية مرتكزاً للإيقاع، هي ما يعرف بمصطلح الإيقاع الخارجي. و يمكن أن نحيل في هذا الثأن إلى رأي الدكتور عبد الملك مرتاض و هو بصدد مقاربة نص شعري بإجرائية سيميائية. إذ بثير إلى الإيقاع الخارجي بوصفه مرجعية تراثية حيث يقول: ثم لعلَّ أبا علي أحمد المرزوقي أن يكون ممن أومأ إلى بعض هذا أيضاً حين طالب بأن يكون الثعر مشنملاً على تخيّر من لذيذ الوزن، لأن لذيذه يطرب الطبع لإيقاعه (مرتاض، ب99 (: به ( ) و على مستوى التظظير الغربي يعرفه ريتثارد بقوله: إنّه هذا النسيج من التوقيعات و الإثباعات و الاختلافات و المفاجآت التي يحدثها تتابع المقاطع (جيدة، (91 (: 7هץ). و 
استتاداً إلى هذا الأفق النظري لمصطلح الإيقاع الذي تتقاسمه المفهوماتية و الأدبية، فإننا نلامس صعوبة في استكناه مظاهره بصورة دقيقة.و في هذا الثأن يشير عز الدين إسماعيل بقوله: او الواقع أنّه ربما كان من السهل دراسة الإيقاع في الموسيقى، و كثف هذه القوانين بسهولة فيها، لأنها فن زماني تتضح فيه الصورة الأولى و لا تختلط بشيء أمّا فنّ القول فإن

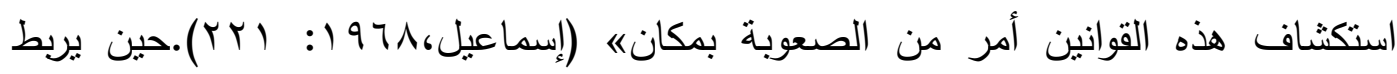
الإيقاع بالأداء مما تولدت لايه رؤبة جديدة لإشكالية الإيقاع كمعلم فني يلزم النصوص الأدبية.إنّ الإيقاع يختلف بحسب إيقاع الوحدة الثعرية في حدّ ذاتها ثم بحسب أداء هذا الإيقاع أي كيفية قراءة النص (مرتاض:^^ ( ).

إننا بتتبعنا لإشكالية الإيقاع من حيث هو مصطلح، ثم من حيث هو أداة إجرائية ترمي إلى تفجير النص من الداخل وربطه بالمحتوى الدلالي الذي يثيعه، نسعى للإثنارة إلى تفعيل السؤال بغية استكثاف الظاهرة الإيقاعية. وبهذا نكون قد اقتربنا من الإيقاع الفني الذي نستشرفه، فيغدو النص الإيقاعي بمقتضى ذلك خطوة تواصلية جديدة في حقل السيميائية. وبهذه الصفة أيضاً، يتحول مفهوم الإيقاع إلى مدخل تأملي يتخذ من النصية اللغوية ميداناً لإنتاج الدلالة وتوليد المعنى. ومن الواضح أننا بنظرتتا هذه إلى الإيقاع نصل إلى بنياته الدلالية العميقة التي لا يعرضها النص على السطح، ولكنها تكون مفهومة بروية تجاوزية تأملية وكثفية إلى مستوى أعمق من الوعي التفكيكي.

الإيقاع القرآني:

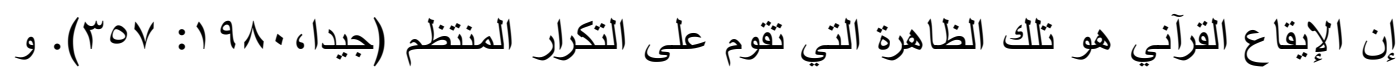
هي نظرة تجعله متميزاً في جوهره عن النصوص الأدبية الوضعية، في كونه يتلوّن تبعاً لاختلاف النصوص من حيث مضامينها و أثنكالها، و يزداد تلوناً، حين يتحوّل إلى لغة كثفية تتلاحم داخلياً عبر النسوج النصية، مما يستدعي طاقة تثقيفية تعمل على تفجيره من 
العمق. و لعل أقرب تعربف يلامس إيقاعية النص القرآني هو ما أثنار إليه بعضهم بقوله: إنّا ألفينا القرآن العظيم يقوم جمال نظمه أساساً في رأينا، على اصطناع الإيقاع العبقري الذي يطبع بنية كلّ سورة من السور بطابع إيقاعي يكون هو الخاصية الأسلوبية التي تبهر و تسحر (مرتاض،rی19 (: 9 § ) ). غير أن الإيقاع القرآني في تمظهره يتخذ بعداً إعجازياً، مدا يعطيه شرعية الحضور بوصفه مصطلحاً فنياً كرَّسه المتن القرآني، وأوجده كتقنية فنية اضطلع بها وحده، ومن ثمة فإنّه مظهر من مظاهر معجزة القرآن الموسوعاتية، بحكم ما يتمتع به من جمالية إعجازية موسومة بخاصة تلازم المنهج لها: ولكن معجزة الرسول هي عين منهجه، ليظل المنهج محروساً بالمعجزة وتظل المعجزة في المنهج (الشعرواي،ج (: 7).

وقد تحدث حازم القرطاجني عن الايقاع وما يحدثه من أثر نفسي وراحة معنوية لا حدود لله ويكون نجاح في النص بمدى توافق هذا الايقاع وتغذيته له (القرطاجني، (191 (: r I ) القرطاجني، ابوالحسن حازم (1919 (). منهاج البلغاء و سراج الأدباء،تح: محمّد الحبيب بن الخوصة، بيروت: دار المغرب الاسلامي، طب.

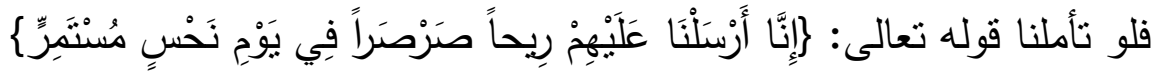
ويعدّ هذه إحدى الأهداف التي جعلت نصّ القرآن حاضراً و خالداً في كلّ الأزمنة.حالياً نعود إلى إيقاع قصنّة سورة عبس.إنّه ينقسم على هذه الوتيرة الإيقاعية المختلفة، و هي في مجملها تتنمي خارجياً و داخلياً إلى فئة:

$$
\begin{aligned}
& \text { أ). فئة- † ى. تواترت عشر مرات. ويسمى (الصائت المديد الألفي المفتوح). } \\
& \text { ب). فئة ـ رَة. تواترت تسع مرات. ويسمى (المديد الرائي). }
\end{aligned}
$$




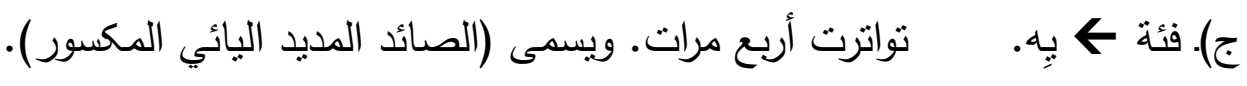

$$
\begin{aligned}
& \text { د). فئة ك باً. تواترت خمس مرّات. و يسمّى (المديد الألفي المفتوح). }
\end{aligned}
$$

و عسى أن يكون الجميل في هذه الإيقاعات أنها تدرك من الخارج و بسهولة، بحيث يمكن الوقوف عليها بمجرد القراءة الواعية الأولى. و الأجمل أن هذه الإيقاعات الخارجية الثكل تتعكس عبرها. و داخلياً إيقاعات أخرى المضمون تتكاتف معها، الأمر الذي يجعلهما متحدين بحيث يصعب الفصل بينها. و هي سمة حداثية أصلها الجرجاني، لأنه:لم يكن

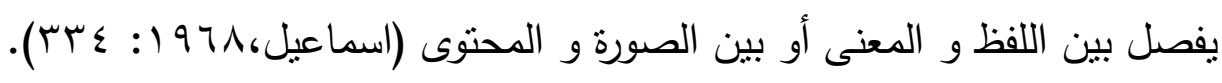

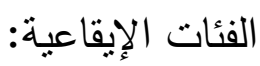

ا . الفئة الأولى: 》ى《 نواترت عشر مرّات. وهي:اتولّى - الأعمى - يزّكّى - الذكرى استغنى - تصدّى - اللّ يزّكى - يسعى - يخشى - ثلهّى ن.نرى أنّ الفونيم (ى) يتحكّم في بداية هذا النظام الإيقاعي حيث يجعل الآيات شكلاً و مفهوماً على على وتيرة واحدة و

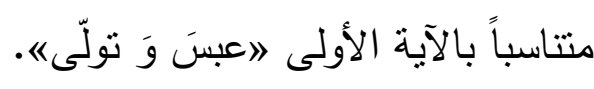

عبس: أي بسر و قبض وجهه. و أن جاءه علة ل تولى أو عبس على اختلاف المذهبين وقرئ آن بهمزتين وبألف بينهما بمعنى ألئن جاءه الأعمى فعل ذلك وذكر الأعمى للإشعار بعذره في الإقدام على قطع كلام رسول الله صلى الله عليه وسلم بالقوم والدلالة على أنه أحق بالرأفة والرفق أو لزيادة الإنكار كأنه قال تولى لكونه أعمى.

$$
\text { تولّى: أي أعرض بوجهه. }
$$

يشاهد هذا التشاكل في مستوبين: تشاكل الإيقاع، تشاكل المعنى. 
الف) تشاكل الإيقاع: - ماع

إنّا نلاحظ هذا التشاكل في البنية الصوتية التي تورد في الآيات العشر، وذلك من حيث تتاغمها وتتاسبها وانسجامها، فهي تخرج على وتيرة إيقاعية واحدة.إنَ وظيفة الأصوات الهندسية تظهر بوضوح في كل المقاطع، يبدا بالآلف المديد العثرة ثمّ ما الإستفهام في قوله ( وَ ما بدربكَ)، و كلمة أمّا يتكرر مرّتان، و ما و لا النافية في (وَ ما عليك ألّا)، و الجمات الإسميّة التي تأتي للتأكيد.

نجد استجابة الألفاظ لهذا التلون والتقابل بين الحروف واضحة، الثيء الذي جعلها ـ في ظاهرها استجابة لبنية إيقاعية تخفيها الدلالة الصوتية لهذه الأحرف.

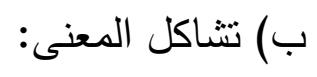

و نعني به المشترك الدلالي لكل من المحمول و موضوعه. فالمحمول هنا أدوات القسم الثلاث، و الموضوع جواب القسم المتعدد.غير أن هذا النوع من التشاكل وجدناه عند محمد مفتاح، و هو بصدد معالجة نص شعري، إلا أنه اتخذ مفهوماً جديداً عنده أطلق عليه التشاكل الرسالة و يجعل فاعليته الدلالية كاملة في فاعليته التواصلية، و بمنل شكلاً من إن أثنكال التداولية، أو رسالة قصدية إفهامية، مما يجعل التشاكل الرسالة، عاملاً أساسياً في

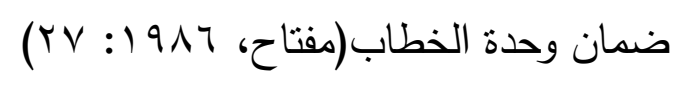

و عنده هو تكرار لنفس البنيات التركيبية عميقة و سطحية على امتداد قول (نفس

$$
\text { المصدر : (Y) أو هو تكرار لوحدة لغوية. }
$$

إن تثاكل المعنى يظهر في القسم و جوابه. و يمكن الاستعانة بهذه الرسمة لنبين هذه المسألة، لتظهر دلالات الأدوات و علاقاتها بجواب القسم. 


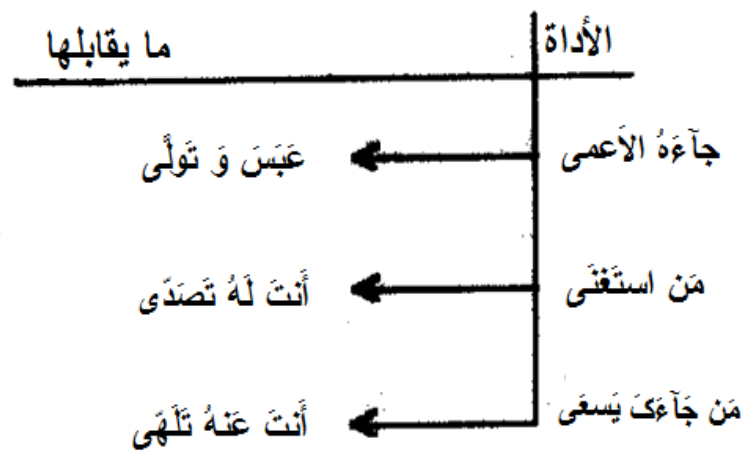

دلالاتها الإيقاعية: نشاهد إيقاعاً واحداً مطرَّداً نلتقي فيه أدوات الثرط و الجواب عنه، بحيث يظهر واضحاً على مستوى الخطية والصوتية.

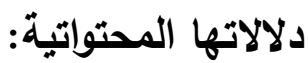

أمّا: المفتوحة المشددة لها وجهان: تكون حرفا متضمنا معنى الجزاء إلا أنه لا يقع بعده إلا

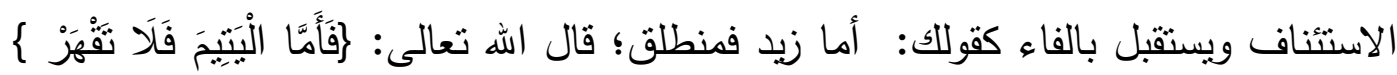
(9) سورة الضحى؛ وتكون حرفا مركبا من حرفين في بعض كلامهم كقولك: أما أنت منطلقا فأنطلق معك؛ معناه: لأن كنت منطلقا فأنطلق معلك. من: غير أن التثاكل بمفهومه السيميائي، نجده قد لامس الإيقاع والمعنى معاً، الأمر الذي جعل المعنى متّدداً مع الصوت اتحاداً لا نظير لله. ولعل هذا يكون قد حصل بوجود ارتباط لحمي عميق بين البنية الصوتية للكلمة وبين النبر الواقع عليها، ثم بين النبر وبين معنى الكلمة (أبوديب، (919 19: 90 ) الثيء الذي جعل هذا النصّ القصصي الذي تجسده سورة العبس في صورته الإبداعية الثمولية تنفاعل فيه المكونات الصوتية والمكونات الدلالية والمكونات الإيقاعية تفاعلاً، يجعل الروئة الكثفية كثيفة. وربما يكون هذا إيقاعاً داخلياً يظهر في تلاك العلائق المتحدة والمتفرقة في الدلالات والرموز، وما ينتج عن ذلك من مكوّنات نفسية وشعورية. وعسى أن يكون هذا التداخل في 
الصوت والبنية والدلالة، هو ما جعل الإيقاع منظوراً إليه على أنه خارجي من جهة ما يثاع من نغم ناجم عن الفونيمات الأربعة. وعلى أنه داخلي من جهة الدقات الثعورية والتموجات النفسية التي رافقت ذلك الإيقاع الخارجي.

غير أنّ الإيقاع الداخلي ينسلّط على الصياغة الداخلية لسطح النص الثعري خصوصاً، والأدبي عموماً، فيتخذ مظاهر إيقاعية تتلاءم فيما بينها داخلياً لنظاهر الإيقاع الخارجي

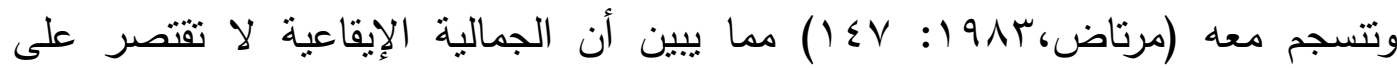
الإيقاعات الخارجية وإنما تتجاوزها إلى إيقاعات داخلية من الصعوبة استكناهها. و على هذا النحو كان نص سورة العبس في فونيماته الأربعة.

إن هذه السيرة الإيقاعية ألفينا الناقد الفرنسي فاليري يشير إليها بقوله:اإنّ النصّ الخالد هو

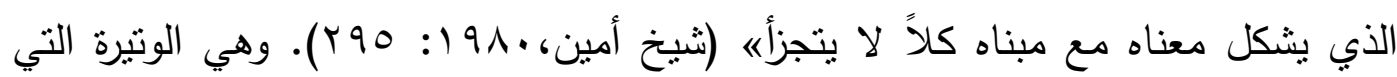

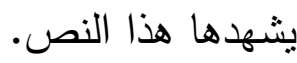

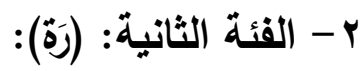

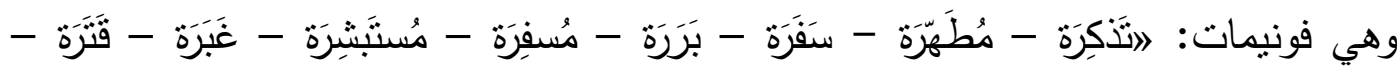

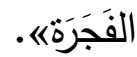

تواترت عشر مرّات. علينا أن ننتبه بأنَ تغيّر البنِية الإيقاعية متصل بتغيّر المضامين التي تتجدّد عبر السياق النصي، الأمر الذي يحيلنا إلى بنية إيقاعية معقدة.

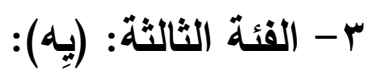

$$
\text { وهي فونيمات: آخيهِ - آبيهِ - بَنيهِ - يُغنيهِ. }
$$

تواترت أربع مرّات. ترتبط هذه الفونيمات بالمضون النصّ، يتحّت اله تبارك و تعالى عن 
يوم القيامة التي يفرّ الإنسان من نوعه، إنّ إيقاع آخر الأيات يتغيّر مع مضمونه و يعدّ من جماليات هذه السورة.

ع - الفئة الرابعة: (باً):

$$
\text { وهواترت خمس مرَّات، وخَتْت الإيقاعات السابقة. }
$$

فإذا القصة كلها، تداخلت فيها هذه الفونيمات وتغيّرت نتيجة التجدد الذي يحدث على صعيد المضمون .ويمكن الاستعانة بهذا المخطط لمعرفة الإيقاع ومظاهره.

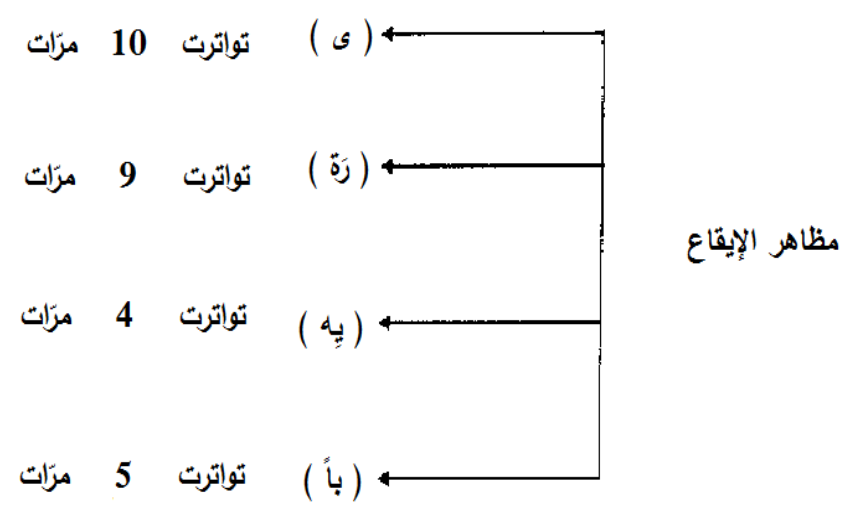

هذاالتتوع الإيقاعي حدث نتيجة التتوع المضموني، وهو يعكس في مظاهره دلالات النص المختلفة. وبنتوع الإيقاع وبتكثيفه عبر هذه الفونيمات تسهل عملية حصر المضامين.يحصل، هذا التذاخل بين الإيقاع والمحتوى، حين يكون النسيج النصي محكّماً على صعيدي الثكل والمضمون. إنّما يتكثف الإيقاع هنا في حركة النمو في نسيج العلاقات الناهض بين هذه المكونات ويلفّ الإيقاع هذا النسيج، يسور فضاء، يدوره وذلك حين يتّخذ الإيقاع شكل التواتز 
المتجول في النص ككل، والذاهب في أكثر من اتجاه أو المتداخل في حقول دلالات النص

$$
\text { كلّها ( العيد، سمر1 1 . ص (1) }
$$

( السبع عشرة). نشكّل هذه الفونيمات ثماني و عشرون في نهاية المطاف بنيّة النّص القصصي هذا، إضافة إلى مدود أخرى تتبع من داخل النص وهي منتشابكة متذاخلة منل:

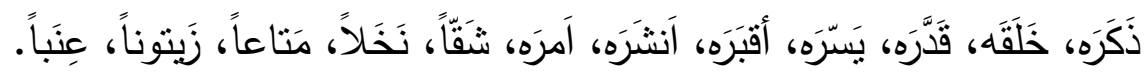

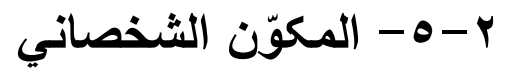

إن الشخصية في القصص القرآنية هي تلك التي تظهر بوضوح، وتقدم بطريقة وصفية شاملة وتعمل على توجيه الأحداث، وهي تتمو وتتطور وفق حركية الشخصية ونموها وتطورها، و تتسم بالغموض والفوضى، بحيث لا يظهرها السرد إلا مبعثرة ، ولا تستكثف إلا بالعودة إلى بعض أجزائها المبثوثة عبر النسيج القصصي، وباستتطاق دلالاتها المختلفة. وهي بهذا يمكن تسميتها الثخصبة الجديدة

فأما السردية القرآنية هي سردية نصية أزلية مفتوحة، الثيء الذي جعل الدراسة التي تنشأ من حولها مفتوحة مطلقة تلامس نواحي متتوعة فى النص، إما على مستوى البناء أو على مستوى المضدون. ولعل المقاربة التي تفضي إلى استكناه المكنتزات والمقدرات الجمالية الإعجازية التي يتمتع بها النص القرآني هي تلك التي تلامسه من نواح شتى، وتلاقحه من زوايا مختلفة لأن كل عمل سردي يجب أن يدرس من حيث السرد ومن حيث الحدث، و الثخصيات و الحيز، و الزمن، و خصائص بناء الخطاب.(عبد الملك مرتاض، ألف ليلة وليلة/ ^؟)

إن هذا التصنيف أصبح ضرباً من السخرية وجنساً من العبث؛» والحق أنه من العسير تصنيف الثخصيات في أي عمل من الأعمال السردية إلى مركزية وثانوية وغير ذات شأن إطلاقاً، كما هو متعارف في النص السردي بمجرد المتابعة التي تقوم على الملاحظة «(مرتاض،r/ 9 / / و وعلى 
هذا فكثيراً ما نجد شخصية واحدة ثتقاطع فيها كل المسميات فهي ثانوية في هذا الحدث ورئيسية في ذاك وأخرى في الثالث. وهذا في عمل قصصي واحد. الأمر الذي جعلنا نلغي هذه المسميات ونقصبها من بحثنا هذا.

غير أننا حين لجأنا إلى علم السيميولوجيا الذي لهو علم موضوعه أنظمة العلامات أو الرموز التي بفضلها يتواصل البشر فيما بينهم. « (السرغيني، 9NV/ / / ) اكتشفنا طريقة جديدة في بناء الثخصية القرآنية، هي قريبة في تشاكلها مع ما تثميز به السردية الجديدة. وغايتتا هنا ليس إثبات حداثة النص القصصي القرآني، وإنما لنضعه في المكان العلمي الذي ينبغي أن يوضع. إن هذه الطريقة تنهض على اللغة، إذ تجعل الألفاظ ذات مقصدية إفهامية من شأنها أن تحيل إلى خصيصة البناء الاساسى و الجوهري. ״ كل عمل يجعل اللفظة مرتكزاً إبداعياً له، يُفترض أنه يلجأ إلى السيميائية أو البنيوية التي تعوّل على اللفظ بوصفه دالاً، الثيء الذي يجعل الدراسة متماسة مع السيميولوجيا. لأن علم النفس والبنيوبة وبعض المحاولات الجديدة للنقد الأدبي، كلها تدرس الواقعة بوصفها دالة، وافتراض الدلالة Roland Barthes: Elements de Semiologie. ( يعني اللجوء إلى علم السيميولوجياه (DENOEL/ Gonthier. Paris 1970 P ^ و عسى أن تكون هذه الأخيرة كفيلة بتحقيق بعض النتائج التي نرجوها من وراء هذا العمل، لأنها تعتمد على الدوال، ونحن مقصدنا اللفظ بوصفه دالاً وعنه نكنَّفُِ طريقة بناء الشخصية.

إن الشخصيات الموظفة في قصة عبد الله بن أم مكتوم لا يمكن دراستها إلا بواسطة العلامات المُميّزة لها، واللجوء إلى العلامات يقتضي الدوران في محيط السيميولوجيا التي القوم على العلاقة بين العلامة والدال والمدلول، فالعلامة مكونة من دال ومدلول، يشكل صعيد الدوال صعيد العبارة، وبشكل صعيد المدلولات صعيد المحتوى. «(ابراهيم، • 99 ( 9 (9 )

إلاّ أننا فيما توصلنا إليه لم نكن نحفل بالمضدون (المدلول) بل كان مقصدنا الدوال، لأننا ألفينا 
״اللغة تتهض بوظيفة سردية بنائية لا تقل عن وظائف الثخصيات، والحيز، والزمان،

$$
\text { والحدث. «(مرتاض،العدد كص • r) }
$$

إذن عندنا شخصيتين متمايزتين فى هذه القصة يظهران فى الآيات الاولى متلاصقان أحدهما ألى الآخر و هما حسب الظهور:

أ) رسول الله: يُظهرها السرد من بداية القصة أي من: "عبس و تولّى، إلى فأنت عنه تلهّى". وتتجسد بوضوح في الضمائر المستخدمة في هذه الفقرة (عَبسَ،توَلِّى، يُّرِيكَ، أنت، تصدّى، عليكَ، جاوَك، أنتا، تَََْهُى).

فى هذا المقام، المسالة الجديرة بالاشارة هى؛ 》إنّ فعل النّبي(ص) والحال هذه لا يخرج من كونه (تركاً للأولى)، فإنّه بفعله هذا لم يقصد سوى الإسراع في نشر الإسلام عن هذا الطريق، وتحطيم صف أعدائه. و بالإضافة إلى ذلك فإنّ عبد اللّه بن أم مكتوم لم يراع آداب المجلس حينها، حيث أنّه قاطع النّبي(ص) مراراً في مجلسه وهو يسمعه يتكلم مع الآخربن.《( الأمتل/ الجزء التاسع عشر/ (ع) (

و من جانب آخر؛ لانحن نعرف النبي (ص) وحسن أخلاقه وما خصه الله تعالى به من مكارم الاخلاق وحسن الصحبة. حتى قيل إنه لم يكن يصافح احدا قط فينزع يده من بده، حتى يكون ذلك الذي ينزع يده من يده.«(التبيان/ج• //ro9) و كما روي عن الصادق عليه السلام فى هذه المسالة: \ كان رسول الله (ص) إذا رآى عبد الله بن أم مكتوم قال: مرحبا مرحبا والهه لا يعاتبني الله فيك أبدا، وكان يصنع به من اللطف حتى كان يكف عن النبي (ص) مما يفعل به.«( تفسير

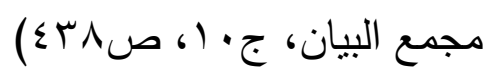

ولكن بما أنّ اللّه تعالى يهتم بشكل كبير بأمر المؤمنين المستضعفين وضرورة اللطف معهم واحترامهم 》 فإنّه لم يقبل من رسوله هذا المقدار القليل من الجفاء. عاتبه الله من خلال تتبيهه على 
ضرورة الإعتناء بالمستضعفين ومعاملتهم بكل لطف ومحبّة. ويمنل هذا السياق دليلاً على عظمة شأن النبّي، فالقرآن المعجز قد حدد لنبيّ الإسلام الصادق الأمين أرفع مستويات المسؤولية، حتى عاتبه على أقل ترك للأولى (عدم اعتتائه اليسير برجل أعمى).《( الأمثل/ الجزء التاسع عشر/ ع (ع) يستوعب هذا العتاب عشر آيات و إن ما يلاحظ على هذه الفقرة، أنها تثقاطع مع نظربة السرد الجديدة في نقطة واحدة. حيث ألفيناها تقوم على مخاطبة الشخصية بصيغة "أنت" مرتين. كما هو واضح في: "وأنتَ عَنه تَلَهَّى، فَأَنَتَ لَهُ تَصَدَّى". وفي ظل هذه التوظيفية اليتحول إلى مفهوم السرد من مجرّد عرض لأحداث أو حالات (وضعيات) إلى نظام من التواصله (تتقلاً عن حسين خمري: تجليات الحداثة . عr . صع V V هذا النظام بإمكانه أن يكثف عن طبيعة التواصلية الجديدة التي تتشئ الصيرورة الخطابية السرمدية عبر الزمن الدعوة إلى الاسلام، مذ هذه القصة إلى قصة الخلاص الأبدي وقيام الساعة.

إن الألفاظ المكوّنة للآيات، تجسد الاهمية الاعتناء بالمستضعفين و التصرف معهم الذي تكثنَّف للنبي بحيث عوتب بسبب عدم الاهتمام و لو بقليل. إن المجسِّ لهذا، هو توظيف عشر آيات و الافعال و الضمائر المخاطبة المستخدمة في نمطية السردية القصصية. و هذا كله يدل على لزوم الاهتمام بهذا الموضوع. فإذا تأملنا هذه الإضافة، وجدناها تحدد طبيعة السرد الباني لثخصية الرسول. فكأن الخطاب فيها موجه لمحمد وحده، وكأن السارد بهذه الإضافة ربٌّ محمد فقط.

عسى أن تكون الغاية من اعتبار الرسول شخصية تتمتع بخاصية الحضور في حركة السردية القرآنبة، هي ما تشي به هذه الفقرة في كونها وظيفة الشخصية من نمط النبوة. وهذا لم يأتِ عرضاً وإنما كان بوعي وقصدية إفهامية، الغرض منها، إعطاء مرجعية دينية للقصة وإضفاء الصّفة النبوية على النسيج السردي.

ب ـ شخصية عبدالله بن أم مكتوم: ما يلفت الانتباه، هو أن هذه الشخصية يعرضها السرد فى

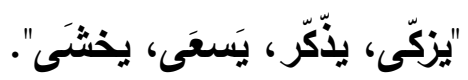




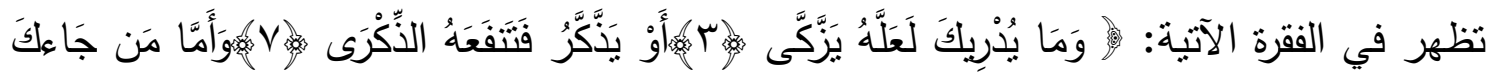

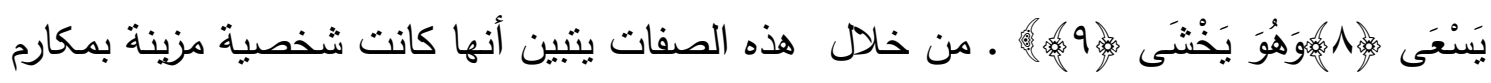
الاخلاق، الأمر الذي أدى بالرّب إلى دعمه و عتاب النبى لاعراضه عنه. " وقد ساقت لنا الآيات حقيقة أساسية في الحياة للعبرة والتربية والإستهداء بها في صياغة مفاهيمنا وممارستتا، فالرجل الأعمى الفقير المؤمن أفضل من الغني المتنفذ المشرك، وأنّ الإسلام يحمي المستضعفين ولا يعبأ

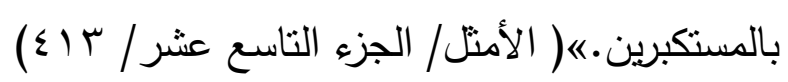

غير أن الاعتماد على ذكر صفات الثخصية دون الإثارة إلى اسمها، يجعلنا نعلن أن النص القرآني قد يتجاوز في بعض طروحه مبدأ تقديس الثخصية ويعوّض هيكلها بصفاتها وأفعالها سلباً وإيجاباً. 》 وفي التعبير عن الجائي بالأعمى مزيد توبيخ لما أن المتاج الساعي في حاجته إذا

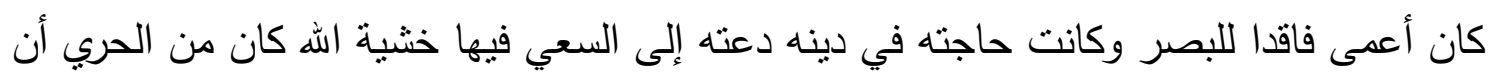
يرحم ويخص بمزيد الاقبال والتعطف لا أن ينقبض ويعرض عنه.《 (تفسير الميزان - السيد

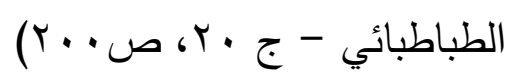
هذا السلوك الفني، يمثل أحد مظاهر الرواية الجديدة الآن. حيث اذهب بعض كتاب الرواية الجديدة في تعاملهم مع الثخصية مذاهب جديدة وأحياناً غريبة حيث أثناروا، إلى شخصياتهم الروائية بحروف فقط كما فعل ألان "روب غرييه" في روايته (الغيرة) حين سمى شخصيته الرئيسية باسم "A" واستعمل كلود سيمون التقنية نفسها في روايته "معركة فارسال" حيث أطلق حرف روف "O" كاسم لشخصيتين مختلفتين"( سعيدي محمد: حركية الثخصية في الرواية الجديدة ـ تجليات

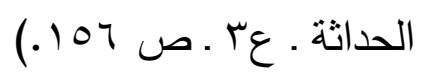
الموقف هنا تغير، حيث أُثنير إلى عبداله بن أم مكتوم بضمير الغائب فقط. و خاطب الله رسوله بضمير المخاطب بعد ضمير الغائب و هذا الالتفات » دليل على زيادة الإنكار كمن يشكو إلى بلى

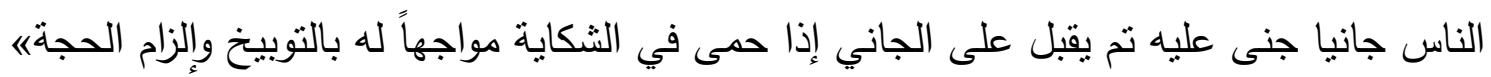




$$
\text { (الكثاف،أبو القاسم محمود بن عمر الزمخشري، الجزء الرابع،صه؟) }
$$

ولعل هذا التحول في طبيعة المسار العمودي، يعود إلى التلون في توظيف الثخصية، بحيث تكون فيه مؤدية لدورها بصورة عادية (مثلاً: شخصية الرسول هنا)، وفجأة يلغيها السارد، ويحل محلها دون شعور منها، وهي تقنية فريدة .

ج) ـ منزلة الشخصيات:

إن الثخصيات الموظفة في القصة خبرية، وصفية، سردية، تقريرية، قريبة من الحواس، لم تتشكل على لسان راوٍ أو مبدع، بل تشكلت وتبلورت من خلال ما تمارس من سلوك وحركة ومواقف، كثفت عنها بنفسها مرة وكثف عنها السارد أخرى.

وعسى أن يكون الأمر الملاحظ في طبيعة الثخصيات . هنا . هو التوازن الملحوظ بين الثخصيتين المسخرتين في هذه القصة، من حيث جانب الحَيّز المخصص لهما، وأيضاً ألفينا ظاهرة سردية، وجديرة بالمتابعة، تمثلت في، أن السردية ـ وهي تصف في إحدى الثخصينتين وصفاً ظاهرياً .، ينضوي تحتها . وبطريقة صامتة . حديث عن الشخصية الثانية. بمعنى أن هنالك شخصيتان متمايزتان في مجال توظيفهما:

فثخصية الرسول صلى الله عليه وسلم من منزلة الأنبياء، حيث عالم الملكوت، كون الاستجابات والانفعالات والتواصل والعطاء والاستمرار وفيض العواطف. ينضاف إلى ذللك المدد القبلي، وهي من وسط اجتماعي قنوع، اكتفى بما أعطاه الخالق، ورضي بذلك. استمدت شرعيتها من الملأ الأعلى، ثم وجدت الكون الأرضي مجالاً لبسطها.

أمَّا عبداله بن أم مكتوم من منزلة المستضعفين، حيث الفقر، و الايمان، و العمى. ونجد مكانته واردة إلى الذهن من خلا كل الآيات أو السور التي كانت تعالج عبداله بن أم مكتوم و هو يخشى من اله. 


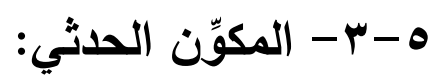

تتقسم القصّة عبداله بن أم مكتوم إلى برنامجين سرديين، يكوّنان أحداث القصّة، ويتشكلان خطابها وبنظمان صبرورتها، وهما برنامج البطل (الرسول) وبرنامج البطل الثانى (عبداله بن أم مكتوم).نظراً على هذا أنّ هذا الحدث وجدناه يتجسّد في مستوبين: الثكل والمضمون.من حيث المفهوم و المضمون يُمارس تَحولٌ على مستوى المسار المحتواتي بالنسبة للشخصيتين المكونتين للبرنامج السردي الذي هو المجموعة من الوحدات السردية المتعلقة بالتركيب التوظيفي الذي يمكن

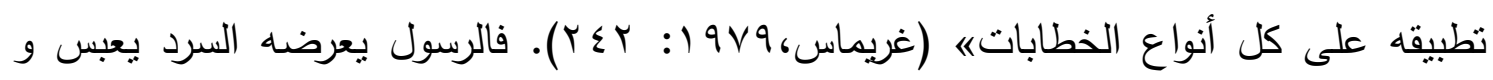
يتولي لان ياتيه الاعمى فى بداية القصة و يواجه اعتاب الله و يندم من عمله فى النهاية. أما عبداله بن أم مكتوم فإنه يُعْرض ضمنياً من موقف الضعف، لينتهي في أحضان الكرامة، فيعظمه الهه و رسوله من بعد العتاب. لكن من جهة الثكل، نشاهد الرسول يشغل حيزاً يكفل له التحرك عبر القصة. هكذا يشغل البطل الثانى حيزا كبيرا من القصة والبنية الواضعة له، يظهر فيها الوصف داخلياً وخارجياً، لتتهي إلى اكرام الاعمى بعد عتاب الرسول من جانب الله. و من جهة خصائص البناء، فنحن نلاحظ بأنّ الأحداث تُمارِسُ البناء والهدم في لحظة واحدة، وذلك عن طريق السارد (اله).

$$
\begin{aligned}
& \text { بَسَسَ وَتَوَلَّىى..الى } \\
& \text { والتي صُوّر فيها } \\
& \text { بب التبى يعاقب }
\end{aligned}
$$

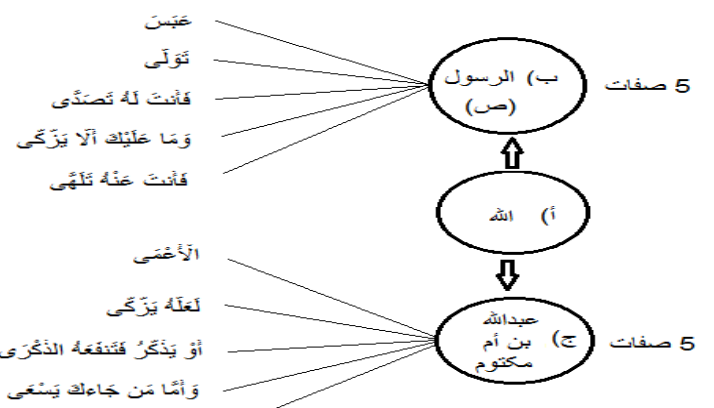

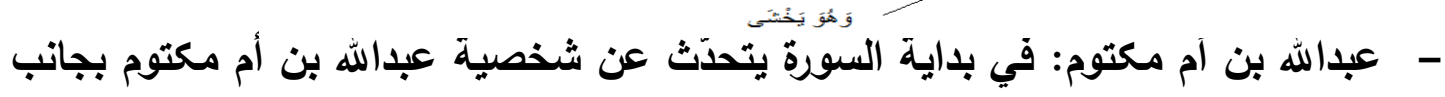
الحديث عن الشخصية الأولى، أي من قوله: اأن جاعه الاعمى..إلى و هو يخشى". هذه 
الآيات نرمز إليها بـ (ج)، والتي تجسد صورة عبدالله بن أم مكتوم من الداخل ومن الخارج.

- السرد الباني: نقصد منه النصّ القرآني، والذي هو في جوهزه الخالق نفسه. نرمز إليه بـ (أ). إن علاقة (أ) بـ (ب) تظهر في الصفات الخمس التي يوحي ظاهرها من أن الرسول قام بعمل لم يعجبه الله. أما علاقة (أ) بـ (ج)، تظهز حينما أحالنا على صفات (ج) الخمس التى يظهر ضعف ابن أم مكتوم و خثيته من الله. ولعل الأروع، هو الاتساق والانسجام بين (ب،ج)، وظاهرة الإيقاع المرافق لهما، بحيث نجد الإيقاع في تطابق تام مع مضمون (ب، ج). إن إيقاع (ى) يتواتر ه مرات و من جانب آخر ايقاع (ى) يتواتر ه مرات. وبرؤية كثفية مبنية على قراءة واعية نعتمد فيها على المقارنة، نكتتف الانسجام العجيب والمذهل بين الإيقاع المرافق لآيات (ب)، (ج)، والمضمون الذي يجسدانه والغريب، حتى بالأرقام. و الآتي يوضح هذا:

فإِن ه(إيقاع ى) و ه(صفات الرسول) نساوي • (. وه (إيقاع ى)، و ه(صفات عبداله بن أم مكتوم)، تناوي • (. من خلال هذا نجد النص يتحرك في فضاء عشرين صفة تلامس الإيقاع

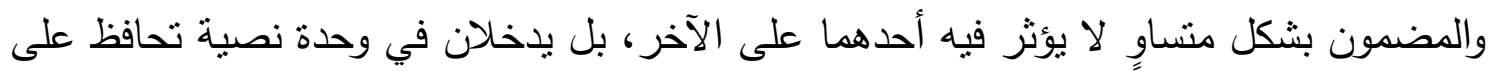
مبدأ الإيقاعية الذي تتهض عليه نصوص القرآن من جهة، وتجدّد المضمونية من جهة أخرى. وعلى صعيد آخر نجد النص يتحرّك في فضاء من التصورات الأساسية التي يعمد السرد القصصي لاستلهامها في بناء شخصيتي (ب)، (ج). ولعل الثكل الآتي من شأنه نوضيح علاقة

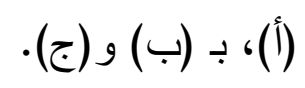

هذا الثنكل يوضح علاقة (أ) بـ (ب) و (ج) من حيث البناء، ومن شأن هذه العلاقة الثنائية السعي إلى اكتثاف المعنى الباطني للغة في دلالتها الإيحائية 》هفرداتها البانية والمهدمة للعقيدتينه من 
حيث إنّ النصّ مؤسس من علاقات غيابية وأخرى حضورية الفالعلاقات الغيابية علاقات معنى

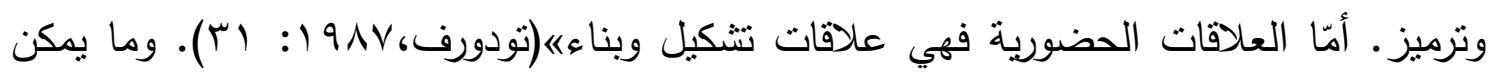
ملاحظته هو الاختزال المطّرد في بنية السرد القصصي كبنية لغوية، فيها الجمل قصيرة ومركزة، تفيض بالدلالة، ومع اختزال عبارات قصة هذه، تتعمق الدلالة القصصية. ولعلنا في استخدامنا للجداول والأرقام لم نكن ننشد إلا تجلية ما كان خفياً وراء هذه الدلالات القصصية. غير أن احضورها في النص يتداخل مع الإثارات اللغوية الصوتية، ويجعل الكتابة

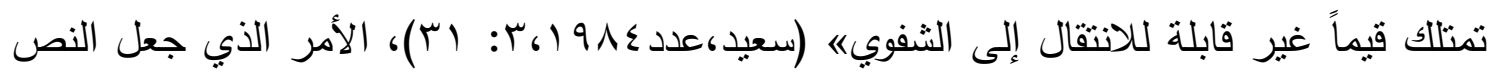
القصصي القرآني مخزوناً دلالياً، كل عبارة فيه تفترض أن تحمل دلالات معينة، وكل إيقاع فيه يعكس دلالة النص التي سيق فيها هذا الإيقاع، وكل سرد يتخذ مستوى متميزاً يجسد الصورة التي عليها القصة القرآنية. وكل شخصية فيه نتوقع لها بناءً خاصاً بها يفرضه المضمون الذي يرافقها. وكل هذا التلون يمنل في نهاية الأمر إنتاجاً دلالياً عبقرياً.

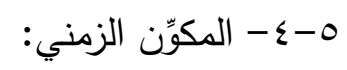

الزمن أحد العناصر الإجرائية المشكلة للحمة الخطابية في القصة القرآنية وبحكم الموقع المتميز الذي يحتله في منظومة السردية الجديدة، فإنه يظل ينظر إليه بوصفه الثظية الأولى لتشكيل الغورية النصية.بعتبر الزمن ظاهرة أدبية وفلسفية تتجلى بصورة خاصة في نتاجات أدباء هذا العصر (إبداعاً وتتظيراً) لأن إثكاليته نتبع من داخله، فهو لم يعد ذلك الزمن المحصور في المجالات النحوية المعروفة، بل اغتدى زمناً مطلقاً مفتوحاً منل الوجود. غير أن (الزمن) يبقى في غموضه، شأنه شأن سائر القضايا التجريدية التي لم يقو على تفكيكها الدين والفن والقلسفة. وفي هذا الإطار يقول باسكال ״إن الزمن من هذه الأشياء التي يستحيل تعريفها، فإن لم يكن ذلك

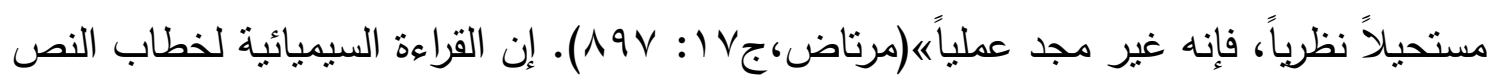
القرآني- وبخاصة ما يتصل بمكونه الزمني- تحيلنا على زمن يتمظهر بتمظهرات فلسفية وفنية، 
فإذن مفهوم الزمن ييقى غائماً عائعاً، مهما بلغ تتظيرنا له، فإننا لن نصل إلى تحديد ماهيته ومعرفة خباياه إلا ما قننه النحويون. ولعل هذا التوجه في غموض الزمن راجع إلى منظومة القرآن النصية، بحيث » أصبح للقرآن زمن نسنطيع أن نسميه زمن القرآن زمن الوحيه( عبد الحميد

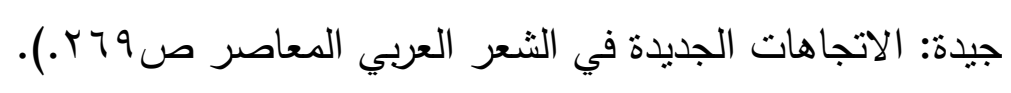

لكن هذا، أدى إلى رؤية جديدة لفهومية الزمن، بحيث هذا التتوع والتضاد في الزمن، من شأنه خلق

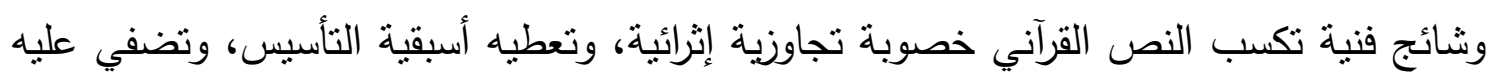

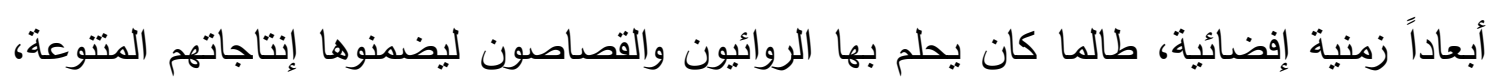
لأن توظيف الزمن يظهر بوضوح في الأعمال السردية ارولاسيما فن الرواية الذي فيه وحده تتجلى ليهل

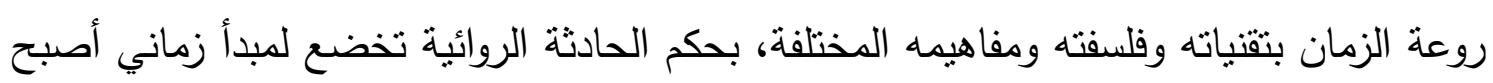

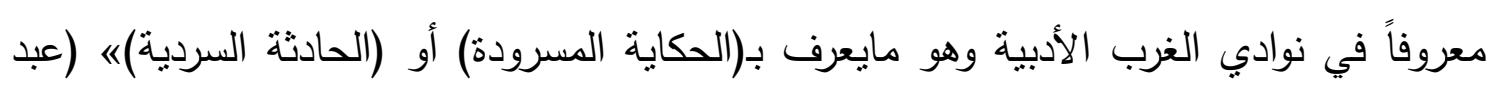

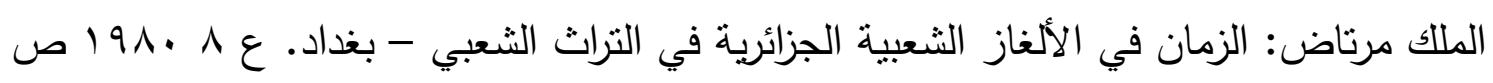

أما زمنية هذه القصة، فنجدها تتخذ صوراً مختلفة تتقاطع فيها بعض أنواع الأزمنة المعروفة وغير المعروفة، الثيء الذي جعل زمنيتها مطلقة وهو ما نفصله الآن:

ه-ــ-1 - الزمن النحوي:

ينبثق الزمن النحوي فى القصة من النظرة الاستشرافية التي تعد إحدى غايات هذه القصة.فبالرّغم من أن أحداث القصة وقعت قبل نزول الآيات -خاصة تلك التي تصف الوليد بالزنيم -إلا أنها

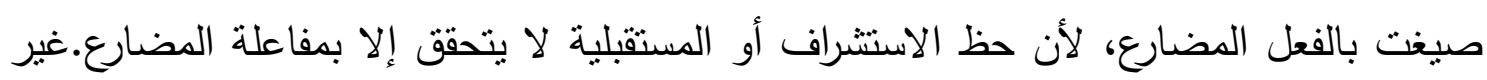

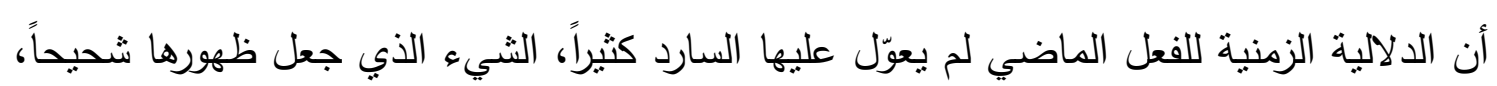


لأن حظ الاستحضارات الذاكرية الناشئة عن الماضوية كان غائباً أو كاد، ورغم ذلك وبمقتىى هذا الغياب نجد النص متتازعاً من زمنيين نحوبين طغى أحدهما على الآخر. - - - - - - - - - الزمن الماضي:

ينحصر في خمسة مواطن من السرد: (عبس)؛ لأنّ العبس و الجهامة مسألة قضى الله فيها و انتهى أمر حكمها، لذلك جاءت بالصياغة الماضوية. و (تولى)؛ حدث بجانب العبس و العراض و عدم اكتراث عملان بدأ السرد القرآنية بهما و الإعراض منل العبس انتهى لهذا جاء بصيغة الماضى. (جاء) فى "أَن جَاءهُ الْأَعَْى" علة مجىهه بالماضى نزامنه بالعبس و التولُى و فيه تعليل لما ذكر من العبوس بتقدير لام التعليل. ال في الآيتين عتاب شديد ويزيد شدة بإتيانهما في سياق الغيبة لما فيه من الاعراض عن المشافهة والدلالة على تشديد الانكار ه (السيد الطباطبائي،ج. ب: 99 ( ).

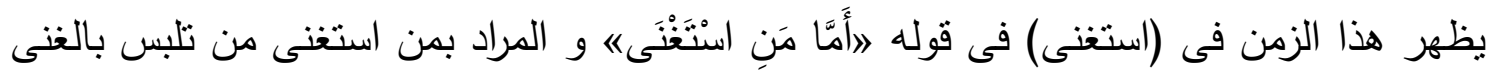
ولازمه التقدم والرئاسة والعظمة في أعين الناس والاستكبار عن اتباع الحق (نفس المصدر : . ب؟). فأستمل فى الزمن الماضى لان استغناء الثخص المراد به موضوع محرز فى بداية القصة. و (جاء) فى قوله لاوَ أَمَّا مَن جَاءكَ بَنْعَى" تاكيد على معنى (جاء) فى الآية الثانية فأستعمل فىى الماضى بسبب اكمال العمل.

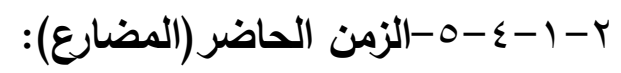

تواتر تسعة مرّات، و هي بالترتيب:ايدريك، يزّكّى، يذّكّر، تتفعه، تصدّى، يزّكّى، يسعى، يخشى، تلهّى". لعلّ الملاحظة الأولى التي ينبخي ذكرها، هي أن زمنية المضارع، هي الغالبة، لأنّ بنية المضارع بنية متحركة ناضجة، فاعلة للأحداث ومفعّلة لها.

جاء (يدريك) بصيغة المضارع بعد إتيان الآيتين بالماضى. إذ السارد يخاطب النبى (ص) فى الزمن الحاضر بعد اكمال السرد فى المرحلة الاولى أى بعد القول عن اتبان الاعمى و العبس و 
اعراض النبى. " و فى مجىه في سياق الخطاب، تثديد التوبيخ وإلزام الحجة بسبب المواجهة بعد الاعراض والتقريع من غير واسطة و في الإخبار عما فرط منه ثم الإقبال عليه بالخطاب؛

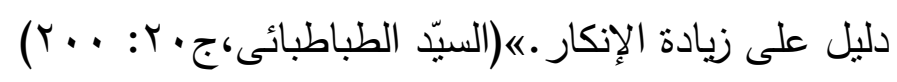
و (يزِّّكى) فى الآية يدل على المستقبل بقرينة "لعل" ، و ما بعده (يذّكّر و تنفعه) بمعنى و

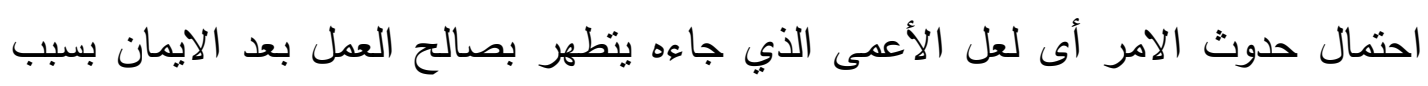

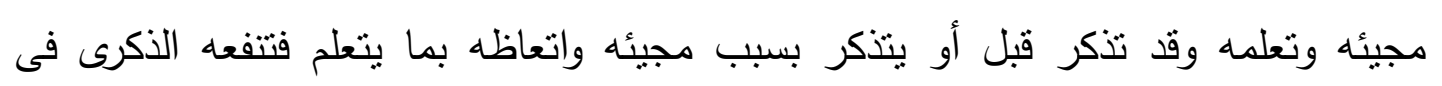
المستقبل فيتطهر.(نفس المصدر :... إ) إذن هذه الافعال تدل على المستقبل بسبب وجود القرائن.

و فى (تصدّى و تلثهّ) يُخاطَب النبى(ص) معاتبا و لاجل شأن النبى أنت الآية بصيغة

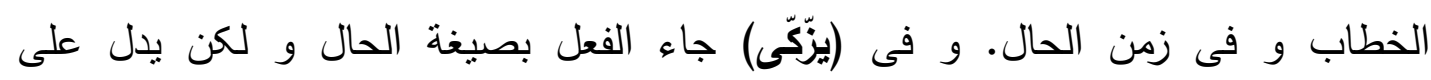
المستقبل. و فى (يسعى) أى يسعى فى التعليم و هذا الامر يعود إلى الماضى و كان تزامنا

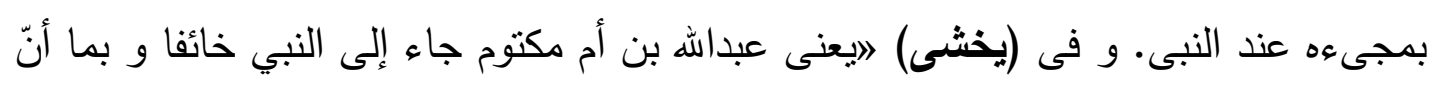
الخشية هي الحذر من مواقعة المعصية خوفا من عقاب الله تعالىه(الطوسي، با: . ـr؟) و

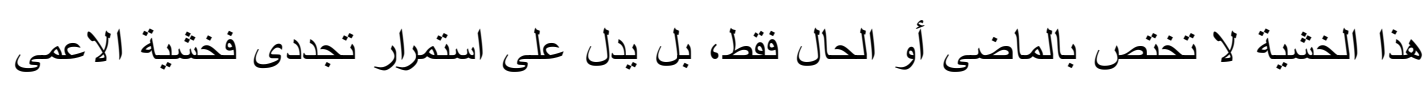

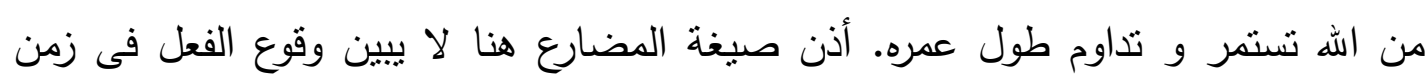
الحال فقط.

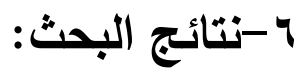

إنَّ القرآن الكريم- و القصّة جزء لا يتجزأ منه - كائن حي و منبع غني لا ينضب معينه و لا

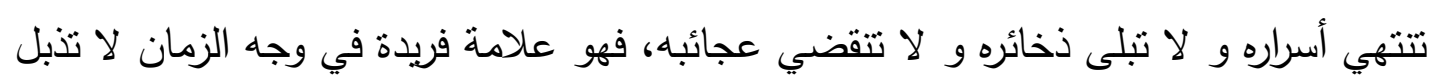

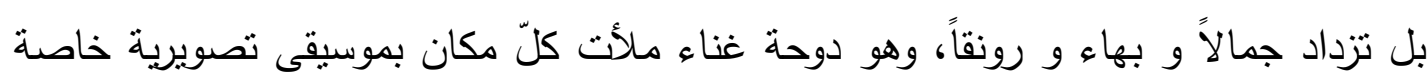

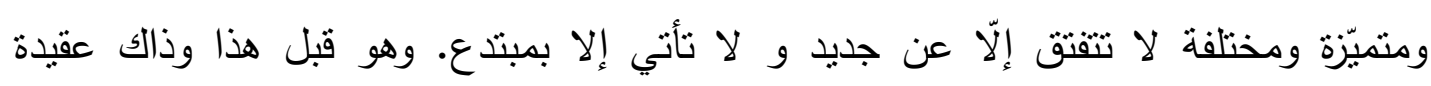


ومنهاج، وفكر وسلوك، ومنهج وشريعة تغمر حياة الإنسان بالفرحة والطمأنينة والنشوان في

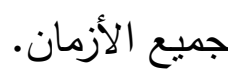

اذا كان القرآن الكريم بهذا الثكل فإن القصة القرآنية مكوّن من مكوّناته الأساسية وعنصر من عناصره الرئيسيّة وجزء كبير من أجزائه، ومن ثمة فهي تحمل الخصائص والمقوّمات والأسس والأساليب القرآنية نفسها وتتميز المميزات ذاتها، ولا تتأى عن ذللك. السرد القرآني في سورة عبس يمتزج بموضوع السورة امتزاجاً عضوياً لا مجال فيه للفصل بينها وبين غيرها من مجموع موضوعات السورة، تلك السلسلة من الحلقات المختلفة

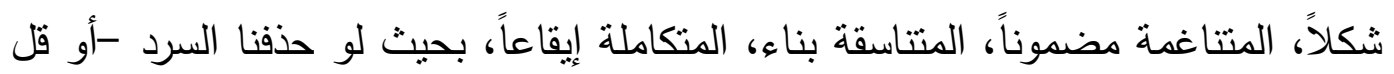
مشهاً من مشاهدها- من موقعها الوارد في السورة لحصل عدم نوازن موضوعي و لإختل المعنى لأنّ السرد يسهم في بيان مضمون النصّ و إيضاح معاني الخطاب وتعميق فكرته لاى القارئ و المتلقي. في جمال أسلوبي و رونق تعبيري و روعة لغوية و وحدة عضوية، لهان و بكلمة واحدة: في إعجاز متكامل.

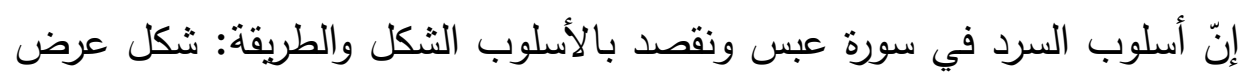
أحداث القصة وطريقة عرضها، أسلوب يسير وبسيط ومقنع وقريب من الإفهام، وسهل على بلى بلى الإدراك ومعجز في التبليغ والإبلاغ. و بما أنّ السرد يتتاول تقريباً كل مواضيع القرآن وتجمع بين محتويات مواضيعه، وتحتوي على جل أو أكثر مراميه وأغراضه، وتستطيع بما تتمتع به من أسلوب القص وطريقة الحكي أن تحقق كل أهدافه.. فإن الاهتمام المتجدد بها والعناية بعناصرها وتحليل مضامينها والغوص في كثف مكنوناتها وتجلية أسرارها ورصد بنياتها.. ما هو إلا عناية بذلك التصوير الدقيق لمعاني القرآن الكريم وموضوعاته ومحتوياته ومفاهيمه وما يريد عرضه.. فهي تتخصها وتمنلاها وتحييها في زمان ومكان وأحداث ووقائع وشخوص، وتفرغ عليها حركية منقطعة النظير يتمنلها المنلقي البصير، ويعيش معها أحسن اللحظات العارف المنذوق، ويستشعرها المؤمن الصادق، ويحتج بها الدار الخبير ، ويفخر 
بها الأديب الملتزم والقاص المفنان.

المنابع و المصادر

ا. عبد الملك مرناض: ألف ليلة وليلة دراسة سيميائية لحكاية حمال بغداد- ديوان المطبوعات الجامعية

r. د.عبد الملك مرتاض:النص الأدبي من أين؟! إلى أين؟! د.و .ج. . rم91 ـ

ץ. سعيدي محمد: حركية الثخصية في الرواية الجديدة ـ تجليات الحداثة . عَ .

ع. عبد اله إبراهيم مع جماعة : معرفة الآخر (مدخل إلى المناهج النقدية الحديثة) المركز الثقافي العربي .

الدار البيضاء. طا ـ ـ ـ 199.

7 . 1 عبد الملك مرتاض: الزمان في الألغاز الثعبية الجزائرية في التراث الشعبي - بغداد. ع ^ • 191 ـ

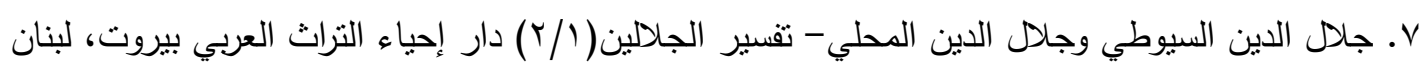
N. نزفيطان تودوروف: الشعرية- نرجمة شكري المبخوت ورجاء سلامة- دار نوبقال - المغرب طا . $) 9 \wedge V$.

9 9. عبد الحميد جيدة:الاتجاهات الجديدة في الشعر العربي المعاصر ـ مؤسسة نوفل ـطا ــ1911. • 1. . محمد السرغيني: محاضرات في السيميولوجيا ـ دار التقافة للنشر والتوزيع ـ الدار البيضاء ـ المغرب . $.19 \wedge \mathrm{V} .1 \mathrm{~b}$

ا ـ عبد الملك مرتاض: ـ بنية السرد في الرواية العربية الجديدة . تجليات الحداثة . عَ .

r r.

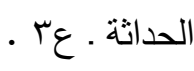

Aj. Greimas : j . Courtes: Semiotique: Dictionnaire Raisonne PP . r $\leqslant r-\varepsilon r .1 r$

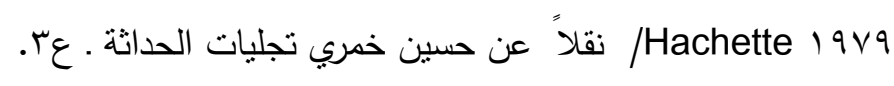

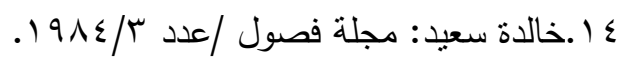

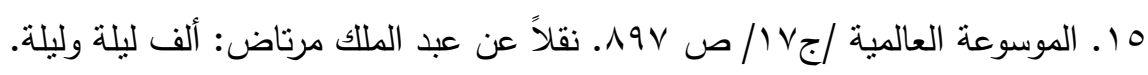


17 ا ـ مكارم الثشيرازى، الثيخ ناصر ، الامتل في تفسبر كتابٍ اللهِ المُنزَل، الجزء التاسع عشر. V ا شيخ الطائفة أبي جعفر محمد بن الحسن الطوسي، التبيان في تفسير القرآن، ج9. 1 ا ـ السيد الطباطبائي، تقسيرالميزان، ج. ب 9 1 أبو القاسم محمود بن عمر الزمخشري، الكثاف، الجزء الرابع • • r. أبي على الفضل بن الحسن الطبرسي، مجمع البيان في تقسير القران، الجزء العاشر. Roland Barthes: Elements de Semiologie. DENOEL/ Gonthier. Paris 1970 P . I 1). 